\title{
Moral education and moral consumption
}

\author{
Ján Kalajtzidis
}

\begin{abstract}
The main aim of the presented paper is to suggest a new possible approach in moral education in Slovakia. The starting point for the presented argumentation is the position that moral education (ethics education) in Slovakia is based on insufficient foundations. One of the possible propositions of how to overcome this shortcoming is to supersede prosocial behavior (insufficient base) with value education and promotion of the development of critical and analytical moral thinking. The paper suggests that one of the possible ways how to achieve this goal is by the help of introducing the issue of moral (ethical) consumption as a topic of moral education.
\end{abstract}

Keywords: moral education, moral consumption, value education, analytical moral thinking

\section{Introduction}

Moral education (in Slovakia known as ethical education) is a school subject which is taught in Slovakia from elementary up to secondary schools as an elective subject. The realization of ethical education is specific in Slovakia as it is based solely on the conception of prosocial development. ${ }^{1}$ When dealing with this shortcoming of moral education in Slovakia in my previous paper I proposed a way to overcome this problem by superseding the influence of prosocial behavior with value education. Value education and promotion of the development of critical and analytical moral thinking instead of prosocial development should be of great help. One of the ways by which moral thinking (in connection to moral values) can be stimulated is the use of real life problems and situations (which are interconnected to the daily life of students) in education.

This paper suggests that one of the most interesting topics which could be helpful in our effort is the issue of consumption and the problems interconnected to it. As an example, ethical consumption might be used. Ethical consumption is a movement which tries to make people critically reflect on the consequences of their daily choices. In today's global economy choices of individual people (moral agents ${ }^{2}$ as economic agents) can have a big impact on the behavior of institutional members of the economic system. Our choices can even have an impact on the system's functionality as a whole. That's one of the reasons why we need to

\footnotetext{
${ }^{1}$ To find out more about the critique and shortcomings of this orientation one might look to my previous paper Value of responsibility in ethical (moral) education (Kalajtzidis, 2015).

${ }^{2} \mathrm{~A}$ moral agent is defined as a subject of morality who is able to fulfill the following requirements: to recognize and understand the moral status of society; the ability to act deliberately and freely; and most importantly he/she must be able to bear the moral responsibility for those actions. This definition is based on my methodological scope: the ethics of social consequences. The ethics of social consequences can be characterized as a contemporary ethical theory and, along with its approach, as a specific form of consequentialism. Non-utilitarian consequentialism (the position which the ethics of social consequences identifies itself with) is a relatively new form of consequentialism which only emerged in the late $20^{\text {th }}$ century. Ethics of social consequences can be characterized as a consequentialist ethical theory with preference given to utilitarianism acts and a case oriented approach. Other aspects of ethics of social consequences are: moderate subjectivity, hedonism and partial eudemonism.
} 
reflect on them and an argument as to why young people (students) need to realize the importance of their choices.

The starting point for the realization of this proclamation is realization of the fact that markets have triumphed over regulations, over common sense and even over morality. The triumph of the markets can be described as the permeation of markets and market-oriented thinking into aspects of life which where traditionally governed by nonmarket norms. Market norms and principles are present in those aspects of our daily life in which they were previously unknown and unwanted. Their presence and ongoing aggressive promotion (and establishing) causes ethical conflicts in our daily lives. Young people must have a possibility to understand these negative changes in society.

\section{Interchanges in the realm of values}

To properly understand the issue we are dealing with so we can correctly present it to students we need to deal with the emerging issue of interchanges in the realm of values. The triumph of the markets (a concept covering the above-mentioned issue) can be described as a process of changes; more precisely interchanges in the realm of values. We can notice the interchange of market values with non-market values and, in addition, an interchange of end values with instrumental values. As a result of this, not only goods, but even subjects (such as moral agents) in society are instrumentalised. The unfortunate consequences of those trends are socio-moral issues in modern society such as exaggerated commercialisation and subsequent materialism and commodification. New forms of consumption such as ethical consumption are appearing and excessive forms of consumption such as consumerism are more common. Those new and excessive forms are bringing even more uncommon trends such as ethical consumerism. Those mentioned and a lot of more complex issues stand in front of contemporary moral education. One of the most important and interesting aspects for moral education might be ethical consumption. ${ }^{4}$

With the regard to claim that ethical consumption is a conscious and deliberate decision to make certain (consumer) choices which are based on moral values and beliefs, it can be added that ethical consumption is responsible consumption which can be characterized by its approach to demand and consumption of products or services. The moral agent, who is understood in this context as economics agent, is encouraged to present and actively follow his own moral values, ideals and/or objectives. In this sense, one of the main aims of moral education must be responsible value education and additionally accurate critical (and analytical) moral thinking. It is important for young people to understand that ethical consumption can be used as tool with which business practices can be transformed, and that our individual choices and actions have public consequences.

There are many ways which can be taught and by which young people as agents can present and actively follow their own moral values, ideals and/or objectives. Four more common ones are: positive buying, negative purchasing, company-based purchasing and fully screened approach. Positive buying means favouring particular products (or services) which will have, for example, a positive impact on the environment. An example can be energy saving light bulbs or recycled paper which can be recommended as preferable for their notebooks. The opposite of positive buying is negative purchasing, which can be understood

\footnotetext{
${ }^{3}$ The triumph of markets is accompanied by activities such as trading in goods which were never meant to be a part of the markets, and, most of the time, are even unsuitable for them. The best example of those goods is business with human organs, security, health care or education.

${ }^{4}$ It is hard to precisely define ethical consumption, and one of the reasons why is the wide range of activities it includes. The definition this paper is working with comes from Matten and Crane, who define it as "... the conscious and deliberate decision to make certain consumption choices due to personal moral beliefs and values" (Matten \& Crane, 2004, p. 290).
} 
as intentional avoidance of products (or services) which are not in accordance with pursued values (ideals, objectives). An example can be battery-cage eggs or air-conditioners. Students can be stimulated to actively help their parents with shopping and experience practical use (or problems connected to them) of those tools. The third way by which ethical consumption can be achieved is so called company based purchasing. This tool is used to avoid a whole company or a sector in business. You can avoid all the products which are offered by McDonald, or even decide to avoid the entire fast food industry as a wasteful way of food consumption. Fully screened approach is the most effective and at the same time most difficult way of ethical consumption. The consumer must look both at the company and at the product to find the most ethical product - the one which fulfills the specified criterion/a best (Ethical consumer, 2014, p. 10).

The motives and moral context of ethical consumption vary a lot. The basic distinction which can be made concerning motives is between the individual and the social. It is possible to assume that moral education can be used to influence both of them. On the one hand, a lot of moral agents make the decision to be a morally responsible consumer on the foundation of their own individual desire to be better person (to be morally responsible, or more generally to do good). On the other hand, the motives which stand behind the decision to become a morally responsible consumer are, in many cases, not individual, but social. Many moral agents feel (or even rationally realize) the need for social change or in some cases want to be a part of social change in public life. Another way to differentiate motives is based on the subject of interest. People are motivated (as individuals or as a part of social movement) to better the political situation, they might have religious motives or their incentives are based in environmental, social or health realms. ${ }^{5}$

\section{Examples of moral consumption}

Organic food could be most probably labelled as one of the first and, today, one of the most popular aspects of ethical consumption. But the biggest impact on daily life must be assigned to the movement called 'fair-trade' which started to grow in the middle of the $20^{\text {th }}$ century, at first in the USA and a little bit later in the UK. The fair-trade movement is represented by the slogan "trade not aid"6 which expresses the will to help but not through charity but by the help of business. This ethical movement is based on the belief that many producers are exploited, face poor working and living conditions, even poverty and at the heart of this problem are international markets. The prices on the markets (commodity markets) are so low that they don't allow producer to provide them and their families with proper living conditions. And of course, their earnings are far from giving them the chance to provide the opportunity to develop and better themselves and their business. The fair-trade movement is, in this situation, a way to encourage and empower those producers and their communities by at least guaranteeing minimum prices for their products, and establishing fair working conditions.

The main aim of fair-trade has been always to challenge the existing economic and business models to create a shift towards concern in society and social awareness. Fair-trade organizations were set out to stimulate redistribution and ensure human rights, improve working conditions and sustain development through increased awareness of consumers (Doherty, Davies \& Tranchell, 2013, p. 161). The currently accepted definition is: "Fair-trade is a trading partnership based on dialogue, transparency and respect that seeks greater equity

\footnotetext{
${ }^{5}$ Tamás Dombos, whose concern is discourse on ethical consumption in Hungary, based his distinction on moral agents and differs in the following way: subjects who are ethical consumers because they feel that it is their moral duty to do so; they understand it as a part of political resistance; they take ethical consumption as a part of care for their family and themselves; they think of ethical consumption as of rational calculus; or as their alternative lifestyle (Dombos, 2012, pp. 131-138).

${ }^{6}$ Another phrase is: working themselves out of poverty.
} 
in international trade. It contributes to sustainable development by offering better trading conditions to, and securing the rights of, marginalized producers and workers - especially in the South" the aim is to support producers, and raise awareness on practices of conventional international trade (WFTO \& FLO, 2009, p. 6). Tme fundamental principles which fair-trade is based on are: fair trade minimum price, provision of social premium, long-term relationships, direct (transparent) purchasing from producers, provision of pre-financing, provision of market information to producers, democratic structures, promotion of consumer education and practice of sustainable production (Doherty, Davies \& Tranchell, 2013, pp. 164-166).

One of the ways to show to students how fair trade works is with the help of example. In moral education, examples are one of the best tools for different educational purposes. There are different kinds of examples which might be used. Dale Jamieson distinguishes four kinds of examples: literary, ostensive, ${ }^{7}$ hypothetical and imaginary. ${ }^{8}$ Each of them has its strengths and weaknesses (Jamieson, 1994, p. 484). The most appealing for the purpose of explaining how fair trade works would probably be the ostensive example. An example of the fair trade approach might be demonstrated using cocoa prices cocoa in the Ivory Coast. While the price of cocoa on commodity markets was around $\$ 1450 /$ tonne the fair trade minimum price was $\$ 1600 /$ tonne $+\$ 150 /$ tonne as social premium. From 2011 it is $\$ 2000 /$ tonne $+\$ 200 /$ tonne. But when the price on the commodity market grows above $\$ 2000$, then the minimum price is the price from the market $+\$ 200$ as a premium (Fairtrade foundation, 2011, p. 4). The aim of minimum price is to pay a producer enough money to cover his production and provide reasonable living for him and his family. The social premium which is paid in addition to the minimum price should allow producers to invest in their community. Investments in schools, medical centres or other activities, which are usually evaluated and approved ahead, are typical.

\section{Critical and analytical moral thinking}

Up to this point, the fair-trade movement looks like an extremely convenient way of how to be an ethical consumer. But there are several problematic issues in this concept. For students to develop critical and analytical moral thinking those issues must be presented and discussed. For example, from the economic point of view, the fair-trade approach can negatively influence producers in a couple of ways. In their view, the setting of a fair trade minimum price can lead to impoverishment of farmers in the long term, as it deforms and masks the real price of the product which should be used as an indicator of the demand for particular products. Students could, for instance, discuss the pros and cons of short-term versus longterm benefits. From the consumers' point of view, the negative aspect of the fair-trade approach might be expressed as a loss of effort from producers as they are not motivated to improve their quality, taste... etc. in connection to the fixed price (The economist, 2006). In this sense, students could discuss differences in incentives and ways of overcoming their limitations.

From the economic and ethical point of view, the fair-trade approach is problematic because of the low redistribution efficiency of money which is earned as an ethical surcharge. Students should try to analyse this issue and look for (discuss) possible solutions. Peter

\footnotetext{
${ }^{7}$ Taken from real life.

${ }^{8}$ The distinction between hypothetical and imaginative is that the hypothetical involves instances of situations or events that have occurred, or could occur. The imaginary involves logical possibilities that could occur only in a world very different from ours. In this sense, imaginary examples should mostly be used for older students in which we can anticipate advanced cognitive functions. Similarly, it is important to comprehend this difference when we are dealing with special types of students, as for example those who are intellectually disabled, but still able to learn (Klembarová, 2015).
} 
Griffiths explain that, in practice, nobody monitors the price which is charged for fair-trade products at the end of the chain: retailers, wholesalers...etc., and so consequently consumers are unaware how much from the price they pay are they paying for the extra (ethical) value. As some studies suggest, customers are willing to pay up to $10 \%$ more for ethically labelled products compared to unlabeled ones (Finkelstein, Landa \& Rios, 2015, p. 171; Griffiths, 2012, p. 359).

Ultimately, the question which might arise as to how ethical fair-trade is. With fair-trade as with other similar morally relevant activities such as (charity) Christmas cards or free range eggs, customers expect that the higher price which is paid is all, or at least almost all, going to the intended beneficiaries. Some assume that it could be at least $80 \%$ of the extra amount paid. In reality the percentage of the extra money paid for the ethicality of a product which will reach the producer is very low and it fluctuates, according to studies, from less than $1 \%$ up to $18 \%$ (Griffiths, 2012, p. 359). Most of the time, it is only a very small amount of money which we pay for a product (the shelf price) that will reach the supplier (grower).

\section{Conclusion}

There might be many unsolved issues which are left unanswered, such as what is the proper age to introduce the presented topic in ethical education (Ethics), what kind of methodology should teachers choose and many others. But it was not the aim of the presented paper to answer them. The aim was to open the discussion and to suggest a new possible approach in moral education in general. As mentioned at the beginning of the paper, the starting point for my argumentation was the position that moral education (ethics education) in Slovakia is based on an insufficient base. One of the possible propositions of how to overcome this shortcoming is to supersede the influence of this insufficient base (prosocial behavior) with value education and promotion of the development of critical and analytical moral thinking. This paper suggested that one of the possible ways of how to achieve this goal is by introducing the issue of ethical consumption which is closely interconnected to today's interchanges in the realm of values.

\section{Acknowledgment}

This paper is a part of the research project - KEGA 005PU-4/2014 Nové výzvy pre učitel'a etickej výchovy v 21. storočí (New challenges for Ethics teacher in the $21^{\text {st }}$ century).

Ján Kalajtzidis received his $\mathrm{PhD}$ in Ethics at the Institute of philosophy and ethics (Faculty of Arts), University of Prešov (2008-2011). He currently holds the position of senior assistant and has been teaching the following courses: Business ethics, Introduction to applied ethics, Professional ethics and Contemporary ethical theories. He specializes in Business ethics (with focus on the financial sector) and consequentialism.

\section{Corresponding author:}

Ján Kalajtzidis, Institute of Ethics and Bioethics, University of Prešov, 17. Novembra 1, SK08078 Prešov (Slovakia)

email: jan.kalajtzidis@unipo.sk

\section{References}

CRANE, A. \& MATTEN, D. (2004): Business ethics: A European perspective. New York: Oxford University Press.

DOHERTY, B., DAVIES, I. A. \& TRANCHELL, S. (2013): Where now for fair trade? In: Business history, 55(2), pp. 161-189. 
DOMBOS, T. (2012): Narratives of concern: Beyond the "Official" discourse of ethical consumption in Hungary. In: J. G. Carrier \& P. G. Luetchford (eds.): Ethical consumption: Social Value and Economic Practice. New York \& Oxford: Berghan Books, pp. 125-141.

ETHICAL CONSUMER (2014): A beginner's guide to ethical consumer. Manchester: Ethical Consumer.

FAIRTRADE FOUNDATION (2011): Fairtrade and cocoa. London: Fairtrade foundation.

FINKELSTEIN, S. R., LANDA, J. \& RIOS, K. (2015): Is there a "fair" in fair-trade? In: Journal of business ethics, 130(1), pp. 171-180.

GRIFFITHS, P. (2012): Ethical objections to Fairtrade. In: Journal of business ethics, 105(3), pp. 357-373.

JAMIESON, D. (1994): Method and moral theory. In: P. Singer (ed.): A companion to ethics. Oxford: Blackwell, pp. 476-487.

KALAJTZIDIS, J. (2015): Value of responsibility in ethical (moral) education. In: Ethics \& Bioethics (in Central Europe), 5(1-2), pp. 13-20.

KLEMBAROVÁ, J. (2015): Etické a morálne aspekty mentálneho postihnutia [Ethical and moral aspects of intellectual disability]. Prešov: FF PU.

WFTO - FLO (2009): A charter of fair trade principles. [online] [Retrieved June 10, 2015] Available at:

http://fairtrade-advocacy.org/images/Charter_of_Fair_Trade_principles_EN_v1.2.pdf

The Economist (2006): Voting with your trolley. In: The Economist, 7th december 2006. [online] [Retrieved June 5, 2015] Available at: http://www.economist.com/node/8380592 